\title{
坐業時における温熱的環境状態と 温熱的快感の関係について \\ Thermal Environment and Sensation of Comfort in Sedentary Work
}

\author{
群馬大学医学部衞生学教室 (主任 沢田利貞教授) \\ 菊池正一・阿部チョ， \\ Masakazu Kikuchi, Chiyono Abe \\ Department of Hygiene, School of Medicine, Gunma University. \\ (Director: Prof. T. Sawada)
}

\section{I. 緒 言}

人間生活のための至適温熱環境条件の決定には, 生体 に対卞る負荷の最小な点を求める生理学的観点, 作業能 率が最高度化発揮される点を求める生产至適温度の観点 招さび人間がもつとも温熱的快感を感ずる点を求める主 観的至適温度の観点の 3 つ立場がある゙”。住居内の日 常生活,坐業時などそは,第 3 の主観的快感はきわわて重 要である。温熱的快感を与える環境条件には個人差があ るが，しかしその範囲の決定は可能である。との問題に 関す文研究成果としては, 二,三の例を古げれば Yaglou らの Comfort zone $の$ 決定 ${ }^{231}$, American Society of Heating and Ventilating Engineers $\oslash$ Comfort Chart 4) (のちに改訂されて American Society of Heating and Air-Conditioning Engineers $\odot$ Comfort Chart ${ }^{6)}$ となる), 日本人を対象としたものとしては丹羽の裸体 時, 着衣時, 性別, 年令別, 季節別妃追究した業績 78 89 などがある。

今回著者らは, 女子電話交換作業者化つき, 環境温熱 条件と温熱的快感との関係を，1年間にわたつて調查す そ機会をえた。その成績をまとめるととにょり，1 年間 を通じて温熱的状態が大きく変動しないょう調節さ礼た 作業室内湉いて，坐業者がいかなる快感域を示すか， 索たこの值はこれまで発表されている業績の示す值と異 なるものである否か, 特化日本人についての丹羽の研 究から約 20 年の隔りがあるが, 両者の間汇差異が方れ るか否かの諸点を明らかにしょうと試みた。本研究は対 象の性抬よび年令が偏つてはいるが，すべて成年女子で 岁つて, 一応平均的な值はらかがい知るととができると
考える。

\section{II. 調查研究対象ならびに方法}

交換作業室冷鉄筋コンクリート建局舎の一部で，面積 は約 136 坪, 有効気積は約 $1,140 \mathrm{~m}^{3}$ であり, 空気調節 装置により気温, 比湿は一定範囲内保たれている。

被検作業者はすべて女子で，総数92名，延 758名であ つた。年令は18〜35才施つているが，90\%は20２7 才であり, 平均年令注 23.8 才である。着衣状態怯 5 月半 ばから10月半ばる゙でビニロン木綿綾織七分袖の作業衣を つけるが, 盛夏にはこの下に薄い下着の及, その他の時 期は下着, セーター類で調節して抢り, 10月半ば以後は 毛織亭つきの作業衣をつけ, その下は合服あるい㤏冬服 の, 上着坣脱いだ程度の着衣である。したがつて年間学 通じ，漂とんど各季節の通常の室内着衣状態と同様であ る。

環境温熱条件汇関する測定項目は, 気温, 比湿, 風 速, 感覚温度捛よび乾力夕冷却率で, 室の 3 力所に扮い

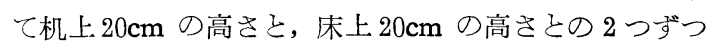
の測定を抬こなつた。

主観的温感覚の調查は, 作業途中 1 名ずつ順次に所定 の用紙の該当項目に○印学記入さ方方法によつて执と なつ火，温感覚の段階は 5 段階, すなわち “暑すぎる”

“やや暑心”，“丁度よい”，“やや寒い”，“寒すぎ る”に分讨，いずれかに○印在つけさせた。その他特に 暑い, または寒い体部执よび自覚症状についても記入さ せた。

測定々調査怡昭和 31 年 5 月から翌年 4 月宗での 1 カ年 にわたり, 毎月 $1 \sim 6$ 日ずつ, 合計 44 回抢となつた。調 
第四

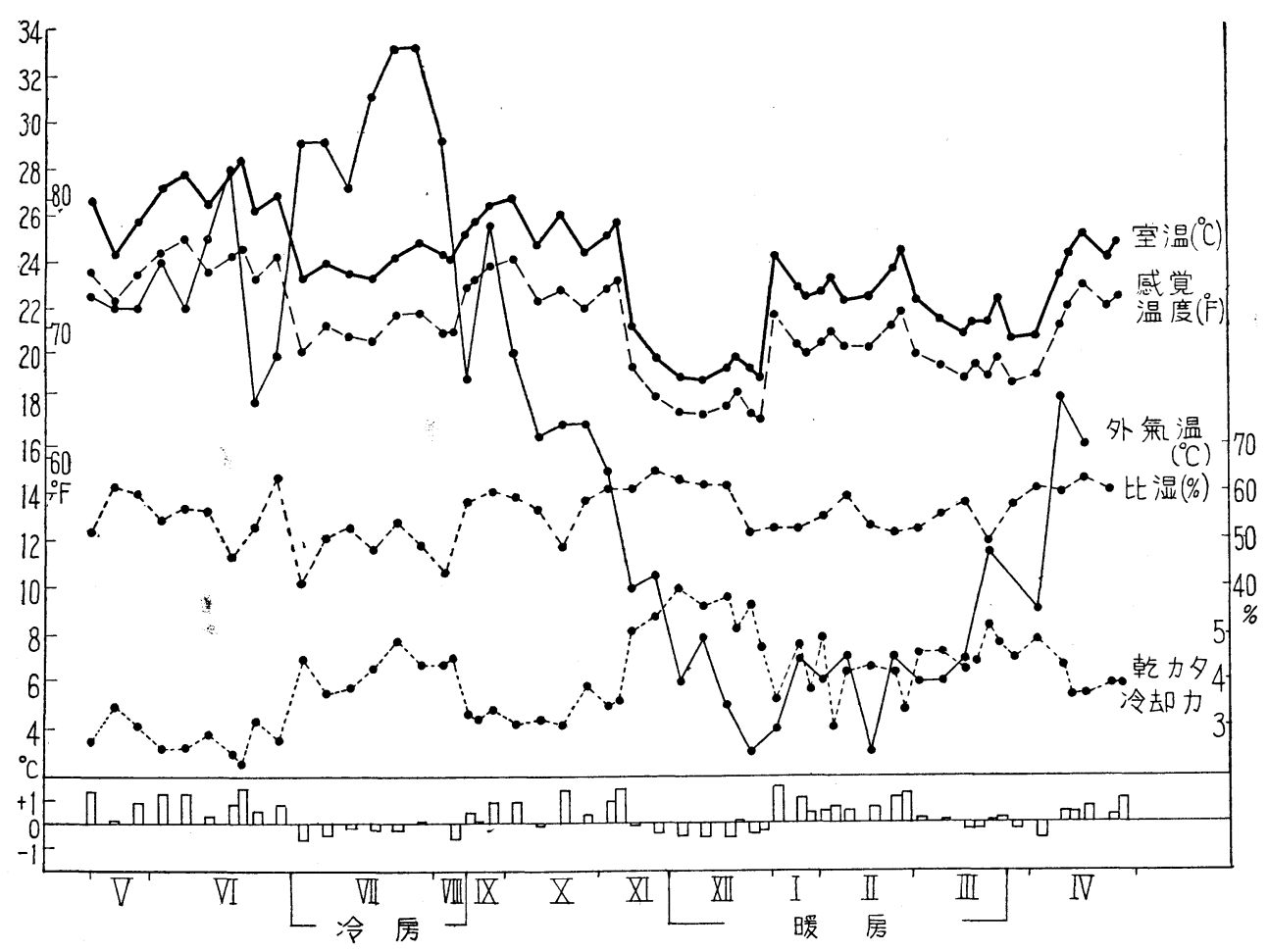

查時刻は午後 1 時から 3 時の間とした。同一日の調査で も作業室内の位置により測定值や主観的温感の著しく異 なる場合は別個汇取扱つて集計した。集計飞当つては, つぎのごとく点数定めた。

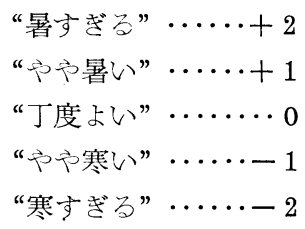

調査日ごとの各段階の百分率を求め, それから当該日 の平均点数算出した。したがつて丁度よいと感ずる者 の多W添ざ点数々 0 に近く, 暑く感ずる者の多い添ぞ+ 側に，寒く感ずる者の多い绔ど一側にずれる。

\section{III. 成 績}

1 年間の環境温熱条件の推移と, 在室者の主観的温感 覚の程度索らわす平均点数と匈示したものの゙第 1 図 である。

調査日の外気温は, $33^{\circ} \mathrm{C}$ から $3{ }^{\circ} \mathrm{C}$ わたり, $30^{\circ} \mathrm{C}$ 差 を示しているが, 室内気温は $28.2^{\circ} \mathrm{C}$ から $18.8^{\circ} \mathrm{C}$ の間で, その差は $9.4^{\circ} \mathrm{C}$ 亿止つている. 比湿の変動が少く, 風速
も常に比較的小であるととろから，感覚温度は気温と清 とんで平行して変動している. 比温はよく調節されて いて, 大部分 $50 \%$ 前後加 $60 \%$ 程度を示している。

温感覚をあらわす平均点数は, その性質から予想され ると抢り，気温の高いときには十側飞偏り，低い場合に は一側作つている。点数が 0 亿近い場合，すなわち快 適已感ずる者の割合がきわめて多い時期は, 夏季冷房時 之 3 月とに存在する。しかしながら両者の気温を比較す ると, 夏季では大約 $24^{\circ} \mathrm{C}$ 前後であり, 冬季では $20^{\circ} \sim 22^{\circ} \mathrm{C}$ である. との点加久て, 夏季と冬季の快感域化相違の あるととがうかがわれる。

気温と温感覚の関係を図示したものが第 2 図である. 1 年を 2 期飞大別して， 4 月加 11 月上旬宗でを温暖 期, 11 月中旬から 3 月未末でを寒冷期とし, それぞれ円 と正方形であらわしてある。温感覚は点数 $0 \pm 0.25$ の範 囲学快適とし，それより十側者暑ず゙るものとして中に 線を入れてあらわし，それょり一側を寒すぎるものとし て中を黒く塗つてあらわした。第 2 図の縦軸汇は机上の 気温, 横軸には床上の気温亲とつてある。机上, 床上の 温度差の著しい場合は少く, したがつて気温の垂直分布 いかんによる温感覚の相違は明かでないが，概して温感 
第 2 図

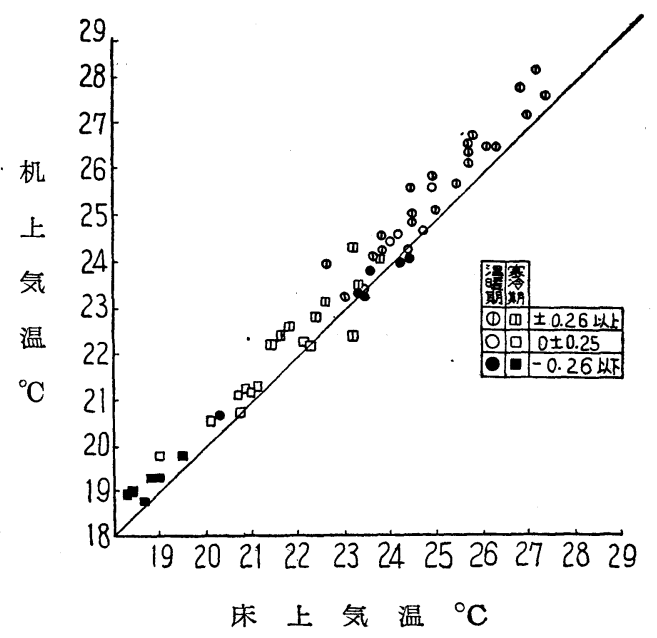

覚の程度は床上よりも机上の高さの気温によつてょり大 きく左右される傾向が認められる。温暖期と寒冷期の快 感域は明らかに異なつていることが知られる（白円の分 布域と白正方形の分布域）。寒冷期では $19.8^{\circ} \mathrm{C}$ 以上 22.2 ${ }^{\circ} \mathrm{C}$ 以下の範囲に抢いて, 例外なく平均点数が \pm 0.25 以 内であるのに反し, 温暖期では大体 $24^{\circ} \sim 25^{\circ} \mathrm{C}$ ところが 快感域とみられるが，との範囲でも例外がかなり認めら れ, 寒冷期の場合ほど判然としていない。

感覚温度との関連は, 第 3 図にみることができる。こ の図に捛いても, 寒冷期の快感域は $65^{\circ} \sim 68^{\circ} \mathrm{E} \mathrm{Tである}$ ととが 比䡬的明膫であるが, 温暖期の快感域は明らか でない。しかし $0 \pm 0.5$ の範囲をとると(図の二重円), 大体 $69.5^{\circ} \mathrm{ET}$ Tか $73^{\circ} \mathrm{E} \mathrm{T}$ の間分布する。

\section{第 3 図}

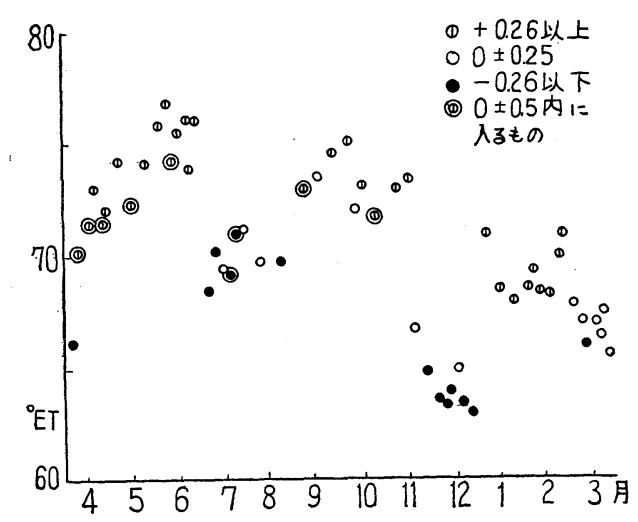

次に温感覚の各段階は, いかなる温度範囲に分布する かを検討した。本調查で得られた温度範团は限られてお
第 4 図 温感賞各段階の分布範囲

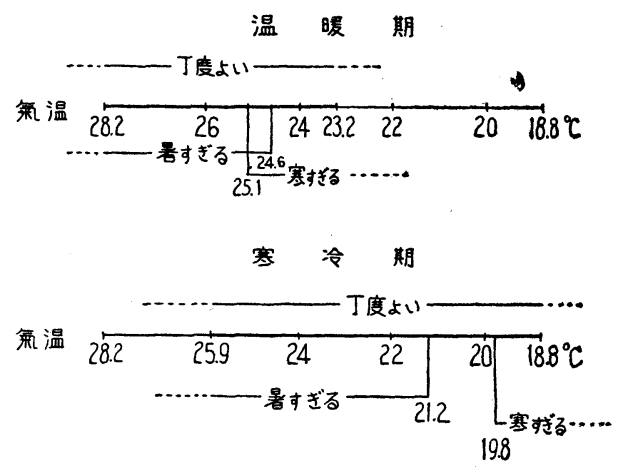

第 1 表

\begin{tabular}{|c|c|c|}
\hline \multirow{2}{*}{ 気 ${ }^{\circ} \mathrm{C}{ }^{\text {温 }}$} & \multicolumn{2}{|c|}{ “丁度よい” の\% } \\
\hline & 温暖 期 & 寒 冷 期 \\
\hline $28.5-28.0$ & 14.3 & - \\
\hline $28.0-27.5$ & 12.4 & - \\
\hline $27.5-27.0$ & 0 & - \\
\hline $27.0-26.5$ & 37.7 & - \\
\hline $26.5-26.0$ & 25.9 & - \\
\hline $26.0-25.5$ & 28.9 & 一 \\
\hline $25.5-25.0$ & 37.2 & - \\
\hline $25.0-24.5$ & 57.5 & - \\
\hline $24.5-24.0$ & 55.4 & 15.4 \\
\hline $24.0-23.5$ & 45.5 & 0 \\
\hline $23.5-23.0$ & 51.0 & 33.3 \\
\hline $23.0-22.5$ & - & 45.6 \\
\hline $22.5-22.0$ & - & 57.8 \\
\hline $22.0-21.5$ & - & - \\
\hline $21.5-21.0$ & 一 & 80.6 \\
\hline $21.0-20.5$ & 0 & 72.5 \\
\hline $20.5-20.0$ & 0 & - \\
\hline $20.0-19.5$ & - & 60.4 \\
\hline $19.5-19.0$ & - & 41.4 \\
\hline $19.0-18.5$ & - & 43.8 \\
\hline
\end{tabular}

りまた気温を連続的に自由に変化させて観察しえなか つたので, その結果は不完全であるが，次のごとくであ つた。“丁度よい”と答えた者は，温暖期，寒冷期と も, 最高気温から最低気温にわたつて(温暖期 : $28.2^{\circ}$ $23.2^{\circ} \mathrm{C}$, 寒冷期 : $25.9^{\circ} \sim 18.8^{\circ} \mathrm{C}$ ) 存在している。した がつて 1名でも“丁度よい”と答える者が出現する可能 性のある温度範囲は，上記の範囲よりも広いはずであ る.さらに “暑すぎる”との答は温暖期では $24.6^{\circ} \mathrm{C}$ 以上 で, “寒すぎる”との答は $25.1^{\circ} \mathrm{C}$ 以下で出現し, 寒冷期 
ではそれぞれ $21.2^{\circ} \mathrm{C}$ 以上拉よび $19.8^{\circ} \mathrm{C}$ 以下で出現した。 “暑すぎる”と “寒すぎる”の出現する温度範囲は, 温 暖期では重り合つているが, 寒冷期では両者のいずれも 出現しない温度範囲が，巾は狭いが存在している（第 4 図）。

温暖期, 寒冷期別に, “丁度よい”との答が各気温に 占める百分率平均をあらわしたのが第 1 表である。

温暖期で“丁度よい”との答が50\%を越えるのは $23.0^{\circ}$ 〜 25. $0^{\circ} \mathrm{C}$ あり り, 最高率を示すのは $24.5^{\circ} \sim 25.0^{\circ} \mathrm{C}$ であ る。しかし最高の值でも57.5\%淿すぎい。との気温範 囲のある場合にはかなりの高率を示すけれぞも, 他の場 合には低率を示すというふらに，同一気温に対する“丁 度よい”の出現率の動摇が大であるため，との気温のす べての場合を平均すると $57.5 \%$ となるのである。とれに
反し寒冷期では $50 \%$ 以上を示す気温は $19.5^{\circ} \sim 22.5^{\circ} \mathrm{C}$ に わたり，20.5 〜 $21.5^{\circ} \mathrm{C}$ の範囲では $72.5 \%, 80.6 \%$ とい う高率を示している。とれは寒冷期では，上記温度の場 合法とんど常に例外なく高い出現率を示すととによる。

気温と温感賞との関係が, 季節の変化につれてぞのょ 万に変動して行くかを明らかにする目的で, 第 5 図を作 成した。ある気温と, その環境で得られた平均点数との 関係を示す点孝, 測定日の順序䘮追つて直線で結んだも のである。各気温の環境で得られる温感覚の程度が, 季 節の変化につれて変動する状態を観察することができ る。 5 月始めの $\mathrm{A}$ 点にはじまり， 1 年間の変動の軌跡走 描いて, 翌年 4 月末の $\mathrm{G}$ 点で終うている。本図の点群は, その性質上右上方から左下方へ分布しているが，第 1 に 気付くここは，上部に斜に分布する点群，下部に同様の

第 5 図

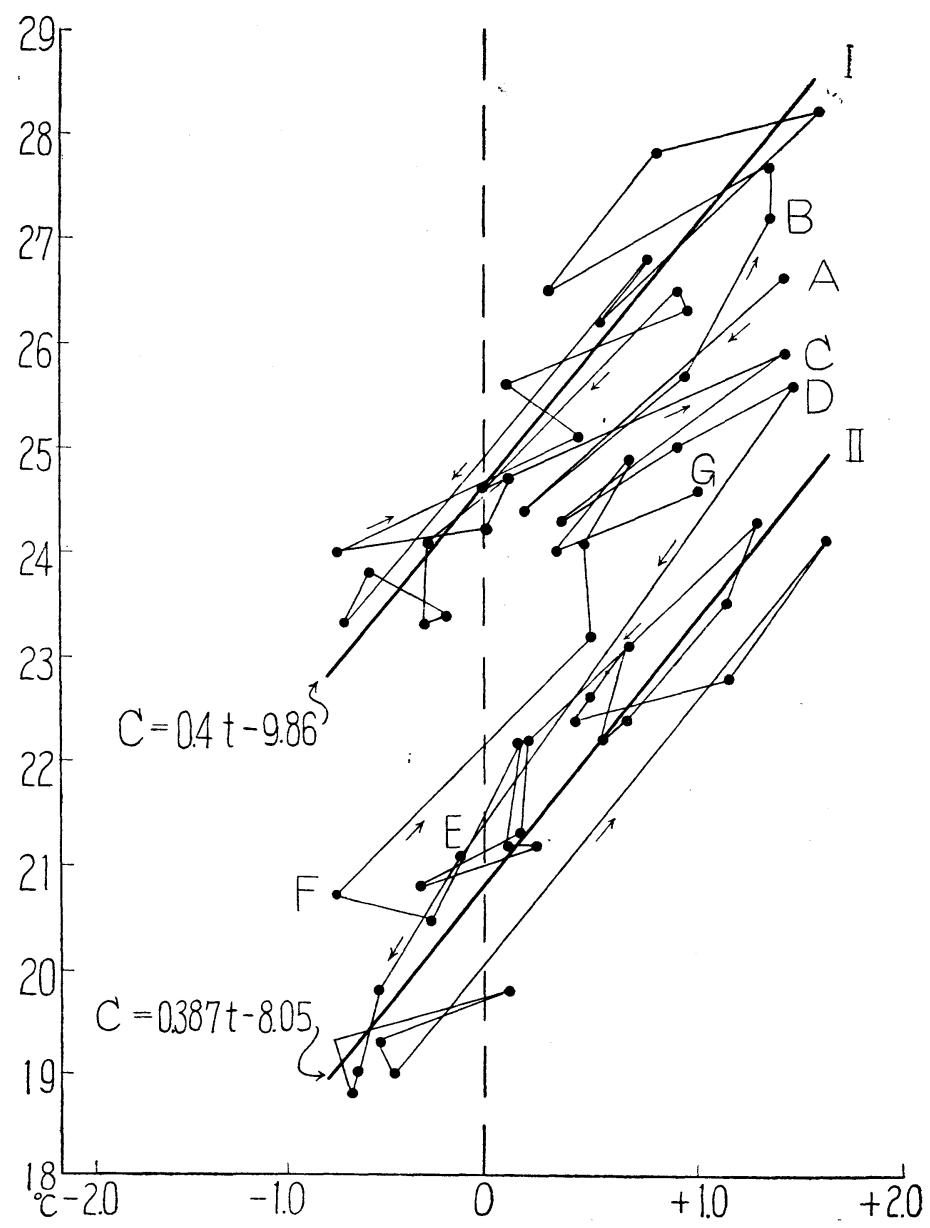


分布をする点群招よびその中間の点群の 3 部分に分けら れることである。出発点の $\mathrm{A}$ 点は上部点群から離れてい るが， $\mathrm{B}$ 点 ( 6 月始め) 加 10 月中旬に至るまでは上部 の温暖期点群を形成し，10月下旬の $\mathrm{C}$ 点に至つてはじめ て上部点群から離れる。その後11月初旬の D点まで中間 期点群を形成し, 11月中旬の $\mathrm{E}$ 点加ら下部の寒冷期点群 に入る。 F点（4 月始め）に至つて下部点群办ら脱し, 以後中間期に入る。

同一温度範囲, 例え $22^{\circ} 24^{\circ}$ 前後の環境状態では, 上部 点群に属すると見做されるものの平均点数は 0 ないしー 側である，すなわち快適かやや寒い方にずれているに反 し, 下部点群化属すると見做されるものは+ 1.0 以上, すなわちかなり暑く感ぜられて扣り, 中間部点群は十 0.5 付近である。また同一温感覚, 例えぼ, $0 \sim+0.25$ の平均点数を与える温度㹥, 温暖期では $24^{\circ} \sim 25.5^{\circ} \mathrm{C}$ 程 度であるのに反し, 寒冷期では $21^{\circ} \sim 22.2^{\circ} \mathrm{C}$ の間である。 この点㘦みても上部点群と下部点群とは別個の集団で あることが知られ, 気温と温感覚の関係には季節差のあ ることが明らかである。そこで上部下部の各点群の分布

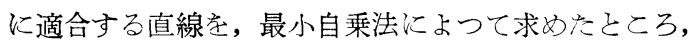
I 捛よび II の直線をえた。両直線をあらわす式は次のと 抢りである。

$$
\begin{array}{ll}
\text { I }: C=0.40 \mathrm{t}-9.86 & \mathrm{C}: \text { 平均点数 } \\
\text { II }: \mathrm{C}=0.387 \mathrm{t}-8.05 & \mathrm{t}: \text { 気温 }
\end{array}
$$

\section{IV. 考按}

温熱的に快適である温度範囲は, 第 1 図によれば, 温 暖期では $23^{\circ} \sim 25^{\circ} \mathrm{C}$, 寒冷期では $20^{\circ} \sim 22^{\circ} \mathrm{C}$ 程度であるこ とがらが゙われる。第 2 図では, 温暖期柱例外がかなり 認められるが大約 $24^{\circ} \sim 25^{\circ} \mathrm{C}$ の間であり, 寒冷期では $19.8^{\circ} \sim 22.2^{\circ} \mathrm{C}$ 間である。さらに第 1 表で， $50 \%$ 以上 が “丁度よい”と感ずる温度範囲は, 温暖期では $23.0^{\circ}$

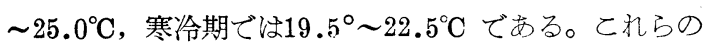
いずれによつても, 温暖期, 寒泠期の各々の快感域を大 体つかむととができ, またとの両者の間にかなりの差が あることも明らかである。

快感域外の気温と温感との関係を考慮に入れて快感温 度扔よび快感域を決定すれば次のごとくである。第 5 図 のI 抢よび II の直線が，点数 0 の位置の垂線と交わる点 の気温をもつて快感温度とすれば, 温暖期では $24.6^{\circ} \mathrm{C}$,

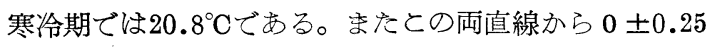
の範囲（75\%以上が “丁度よい”と感ずる範囲）を決定 すると, 温暖期では $24.0^{\circ} \sim 25.3^{\circ} \mathrm{C}$, 寒冷期では $20.2 \sim$ $21.4^{\circ} \mathrm{C}$ となる。感覚温度によつてあらわすと, 第 3 四に
おいて温暖期では $69.5^{\circ} \sim 73.0^{\circ} \mathrm{E} \mathrm{T}$, 寒冷期では65.0

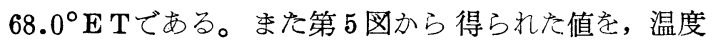
50〜60\%として感覚温度に换算すると, 快感温度は温暖 期 $71^{\circ} \mathrm{E} \mathrm{T}$, 寒冷期 $66^{\circ} \mathrm{ET}$, 快感域はそれぞれ $70^{\circ} \sim$ $72.5^{\circ} \mathrm{ET}$, および $65^{\circ} \sim 67^{\circ} \mathrm{ET}$ となる。

Yaglou \& Drinker ${ }^{3)}$ の着衣時の Probable optimum は, 夏季では感覚温度 $70.5^{\circ} \mathrm{E} \mathrm{T}$, 気温 $24.3^{\circ} \mathrm{C}$, 冬季で

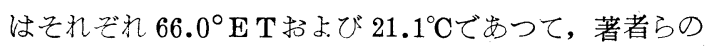
值ときわわて近い。A.S. H. A. E. Comfort Chart ${ }^{6)}$ の 快感線は, 夏季 $71^{\circ} \mathrm{ET}$, 冬季 $68^{\circ} \mathrm{ET}$ T, 冬季の值がや や高くなつている。欧洲の文献では, Küster u. Meixner ${ }^{10)}$ とる Behaglichkeitslinie は, 比湿60\%, 風速25 $\mathrm{cm} / \mathrm{sec}$ の際に $21.9^{\circ} \mathrm{C}$ とつて抢り, Bedford ${ }^{111}$ の英国湾 打ける冬季軽作業時の調査では, 快感温度注 $60.8^{\circ} \mathrm{ET}$, $18.2^{\circ} \mathrm{C}, 70 \%$ 以上が快感をむつ温度籁囲治 $57 \sim 63^{\circ} \mathrm{E} \mathrm{T}$,

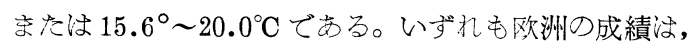
著者らや米国の值に比してかなり低值である。

丹羽9）の日本人男女青年の着衣時の成績によ㣗ば, 快 感域快夏季㹥 $22 \pm 2{ }^{\circ} \mathrm{C}, 70 \pm 3^{\circ} \mathrm{ET}$, 冬季沈 $20 \pm 2{ }^{\circ} \mathrm{C}$, $65 \pm 3^{\circ} \mathrm{ET}$ T゙ある。著者らの值と比較すると, いずれ も丹羽の值は低值である。特仁夏季の快感温度の差が大 きく, また感覚温度の快感線は夏, 冬とむ $1^{\circ} \mathrm{E} \mathrm{T}$ 差 があり,さらに概して快感域の下限が著者らの成績より 低くなつている。とのょうな差は, 20 年の年月の間飞起 つた日本人の身体的変化汇ょるもの加, 摂取栄養や生活 様式の変化などに基くものかは明らかでないが, 以前よ りむょり暖い環境を好むように変つてきていることがう かがわれる。

第 2 図に扮いて, 点数 $0 \pm 0.25$ の場合注さきに述べた と抬り, 寒冷期では例外なく $19.8^{\circ} \sim 22.2^{\circ} \mathrm{C}$ 範囲内で あるのに反し, 温暖期では $24^{\circ} \sim 25^{\circ} \mathrm{C}$ がその範囲已思わ れるけれども例外がかなり多い。第 3 図の感覚温度との 関連老及ても，寒冷期の快感域治きわ的て明瞭である が, 温䁔期のそれは明瞭でない。第 1 表に损いても, 寒

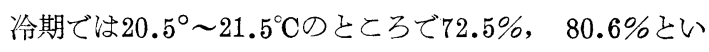
うきわめて高い一致率を示すのに反し, 温暖期では最 高 $57.5 \%$ 程度である。これは気温の上昇, 下降に伴なう 温感覚の変動が, 寒冷期では規則的であるのに, 温暖期 ではさ添ど規則性が著しくないととを示すむのである。 すなわち, 一定の気温の変化があつた場合, 寒冷期な らば大部分の者が一様汇同じ温感覚の変動示示すのに， 温暖期では人により，時期によつてかなり相違があるの である。とのととは第 5 図に执いて, 直線 I 扣よびIIの 周囲の, 点の分散状態を検するため, 推定値標準誤差を 
算出したととろ, 温暖期の直線 Iについては $\sigma c=0.25$, 寒冷期の直線 II 值が小で劣ることからもらかがいうる。着衣状態芜考え

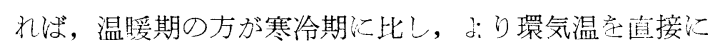
感じやすいはずであるのに，とのょうな季節的差異が認 められるのは, その原因として生理学的状態の相違学考 えるのが妥当で岕るら。

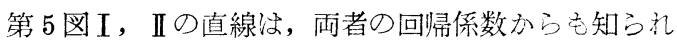
ると扣り，深とんど平行である。すなわち，一定の気温 变化仁伴な弓温感覚の変動の程度は, 温暖期も寒泠期も 陓とんど変りないことが弓かがわれる。本調查では, 直 線 I は 6 月〜 10月初旬汇適合し, 直線 II 月末汇適合しているととろからみると，暑さに対する期 化の期間招よび寒さに対する馴化の期間惊，1 年間のう ちとれぞれかなり長い期間老占めているものと察边られ る。そしてての両期間の中間炕当る時期が馴化の状態の 移行期であつて, その期間は比輘的短く, またこの時期 に㥀線が一方少ら他方へ, その傾斜性不変のまま移動 さるので岁ろう。この間の消息洨，本調査が Yaglou，丹 羽らのごとく人工気候室で招てなつた実験と異なり，作

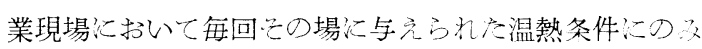
满足亡ざるをえず, 希望する温度変化の巾, 希望する温 度籁囲を自由得られ你かつたので, 十分飞明らか儿寸 るととができなかつた。

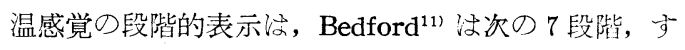
なわち much too warm, too warm, comfortably warm, comfortable, comfortably cool, too cool, much too cool 飞分计て却り，乙の7段階区分法注かなり広く 用いられている。しかし温感覚辇細かく多数の段階儿分 けることは, 被㭘者が相当熟練している場合でないと, 個人差が大きく，告々測定時に上り判断の規準が動く可 能性があり，必ずしも得られた結果が齊一とならない掠 それがある。そこで本調查では, Yaglou らの too wram, comfortably warm, very comfortable, comfornably cool, coldの5段階区分法汅ならつて区分圭試多たが, その結果比較的規則性方る成績孛得た。対象つ数がかな り大であれば，単純な区分で調查在就てなつた方が，被 検者に細かい区分による温感覚の表現主さ些るよりも， より正確汇温熱条件上温感覚已の間の軏続的加規則的

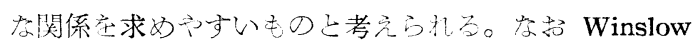
ら ${ }^{12)}$ のどと very pleasant, pleasant, indifferent, unpleasant, very unpleasant に区分すること注, ple-

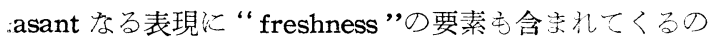
で, 純粋に温熱的感覚の程度主表現するには適当で凉い。

\section{V. 総 括}

女子電話交换作業者延 758名䛃, 電話局内交換 室に扮计る作業時の環境温熱条件と温感覚の関係忌調查 研究した。

1） $75 \%$ 以上の一致率老示す快楜温感域柱湿度 50 ～ 60 $\%$ に捛いて, 温暖期 $24.0^{\circ} \sim 25.3^{\circ} \mathrm{C}\left(70^{\circ} \sim 72.5^{\circ} \mathrm{E} \mathrm{T}\right)$,

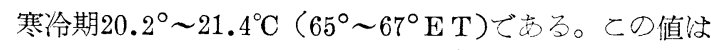
丹羽 (昭和 12 年) の日本人快感帯と比して高值である。

2）気温の上下に伴なう温感覚の変動は, 寒冷期では 規則的であるが，温暖期では規則性の程度が低い。

3）気温に対する温感覚平均点数の回帰直線を比較す ると, 温暖期のものと寒冷期のものとは拣とんど平行し ている。

4） 1 年間に执いて, 暑熱または寒冷に対する馿化の 時期注比較的長く, 移行期は比較的短いことが想像され る。

擱筆に当 り，種々御援助を賜わつた沢田教授，協力を 惜しまれなかつた高崎遇信診療所内山所長ならびに高崎 電話局関係各位に対し，厚く感謝の意を表する。

\section{交献}

1) 石川知福 : 環境衞生学, 吐鳳堂, 昭23.

2) Yaglou, C. P.: The comfort zone for men at rest and stripped to the waist. J. Indust. Hyg. 9, 251 263, 1927.

3) Yaglou, C. P. \& Drinker, P.: The summer comfort zone: Climate and clothing. J.A.S. H. V. E. 35, 1 15, 1929.

4) Houghten, F. C. \& Yagloglou, C. P.: Determination of comfort zone. J. A. S. H. V. E. 29. 515 536, 1923.

5) Yagloglou, C. P. \& Miller, W. E.: Effective temperature with clothing. Ibid. 31, 59 70. 1925.

6) Heating, Ventilating, Air-Conditioning Guide. Amer. Soc. Heat. \& Air-Condit. Engrs. 1956.

7) 丹羽孝一：邦人反対する快感带の測定. I 裸体時 を標準として季節別飞観察せるもの，国民衛生， 14, 487 504, 昭 12 .

8) 丹羽孝一：邦人に対する快感率の測定. II 裸体時 を標準として男女別年秢別飞観察せるもの, 国民 衛生, 505 526, 昭 12 .

9）丹羽孝一：邦人に対する快感帯の測定, III 着服 時を標準として観察せるもの. 国民衞生, 527〜 556 , 昭 12 .

10) Küster, E. u. Meixner, H.: Berechnungen und Tabellen zur Frage des Raumklimas. Arch. Hyg. u. Bakt. 117, 158 178, 1937. 
11) Bedford, T. : The warmth factor in comfort at work. Med. Res. Council Indust.-Health Res. Board. Rep. No. 76, 1936.

12) Winslow, C.-E.A., Herrington, L. P. \& Gagge, A. P.: The relative influence of radiation and convection upon the temperature regulation on the clothed body. Amer. J. Physiol. 124, 51 $61,1638$.

（受付：1958年 6 月28日, 特別揭載) 